\title{
FREE-LIVING TICKS IN A CERRADO FRAGMENT, STATE OF MATO GROSSO DO SUL, BRAZIL
}

\author{
CARRAPATOS DE VIDA LIVRE EM FRAGMENTO DE CERRADO, NO ESTADO DE \\ MATO GROSSO DO SUL, BRASIL
}

\section{Jaqueline MATIAS ${ }^{1}$; Wilson Werner KOLLER ${ }^{2}$; Marcos Valerio GARCIA ${ }^{3}$; Jacqueline Cavalcante BARROS ${ }^{2}$; Maria Dolores ESTEVE-GASSENT ${ }^{1}$; André de Abreu Rangel AGUIRRE ${ }^{4}$; Leandro de Oliveira Souza HIGA ${ }^{5}$; Namor Pinheiro ZIMMERMANN ${ }^{6}$; Renato ANDREOTTI ${ }^{2}$}

\begin{abstract}
1. Department of Veterinary Pathobiology, College of Veterinary Medicine and Biomedical; Sciences, Texas A\&M University, College Station, Texas, USA; 2. Embrapa Gado de Corte, Campo Grande, MS, Brasil; 3. Laboratório de Biologia do Carrapato, Embrapa Gado de Corte /Bolsista DCR Fundect, MS - Governo do estado de Mato Grosso do Sul, Brasil; 4. Pós-Graduação em Doenças Infecciosas e Parasitárias - Faculdade de Medicina, Univ. Federal Mato Grosso do Sul, Campo Grande, MS, Brasil/ Fiocruz/Rondônia, Brasil; 5.PósGraduação em Doenças Infecciosas e Parasitárias - Faculdade de Medicina, Univ. Federal Mato Grosso do Sul, Campo Grande, MS, Brasil/ Laboratório de Biologia do Carrapato, Embrapa Gado de Corte; 6. Universidade da Grande Dourados, Dourados, MS, Brasil. marcosvagar@gmail.com
\end{abstract}

\begin{abstract}
The fatal cases of spotted fever reported in some Brazilian municipalities are generally associated with the presence of ticks and capybaras (Hydrochoerus hydrochaeris). The urban forest fragments where this rodent is present are of great concern. We investigated the diversity of free ticks as well as the occurrence of ticks infected by Rickettsia in one of these fragments, in Campo Grande city, Mato Grosso do Sul state, Brazil. From winter 2012 until the autumn of 2015, using $\mathrm{CO}_{2}$ traps, we collect 1219 ticks, of which 1045 belonged to the species Amblyomma sculptum and 174 belonged to A. dubitatum. Both species were more abundant in spring (September to December) and summer (December to March). Rickettsial DNA was not detected in any of the specimens collected; however, one of the species found, A. sculptum is considered the main vector of Brazilian Spotted Fever, thus deserving constant vigilance by the public health organs.
\end{abstract}

KEY WORDS: Amblyomma dubitatum. Amblyomma sculptum. Tick diversity. Rickettsia spp

\section{INTRODUCTION}

Arthropods transmitting human and animal pathogens are widely distributed in Brazil. Ticks deserve special attention for many reasons, but in particular due to the fact that they exist in high proximity to humans (SZABÓ et al., 2013). In Brazil, Amblyomma sculptum (formerly known as A. cajennense) has been reported as the main competent vector for the transmission of $R$. rickettsii to human beings (LABRUNA et al., 2009).

Presently, 70 tick species have been identified in Brazil (MARTINS et al., 2016; LABRUNA et al., 2016; WOLF et al., 2016), from which 26 have already been observed in the state of Mato Grosso do Sul (LABRUNA, 2016). Researches involving pathogen detection in ticks from Mato Grosso do Sul State confirmed the presence of Rickettsia rickettsii and Rickettsia parkeri (OGRZEWALSKA et al., 2013, ALMEIDA et al., 2013; MATIAS et al., 2014).

The objective of this study was to evaluate the potential role of tick fauna in the ecology of Rickettsian pathogens in a fragmented urban
Cerrado area of Campo Grande city, Mato Grosso do Sul state, Brazil. For this purpose, ticks were collected in order to identify the species present, relating them to their ability to transmit $R$. rickettsii based on pathogens detection and or existing literature.

\section{MATERIAL AND METHOD}

\section{Study area}

This study was performed in a Cerrado forest fragment located in an urban area, in the municipality of Campo Grande, Mato Grosso do

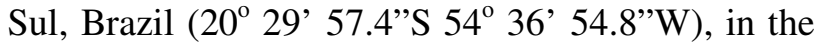
Universidade Federal de Mato Grosso do Sul campus. We chose this area for the study due to the presence of a watercourse, type of forest, typical wildlife inhabiting these ecosystems and its proximity to a location with significant influx of people.

\section{Tick collection}

We collect free-living ticks between a threeyear periods, from winter 2012 to autumn 2015, 
using $\mathrm{CO}_{2}$ traps. Ten traps were used in each collection, one each season per year. We stablished the collection points about 100 meters inside the forest, with a minimum distance of $20 \mathrm{~m}$ between the traps. During this period, we carried out samplings on 12 occasions totaling 120 samples throughout the entire study period. The ticks were taken to Embrapa Gado de Corte Tick Biology Lab, and the adults were identified according to the BARROS-BATTESTI et al. (2006) taxonomic key. The nymphs were fed on rabbits and maintained in B.O.D. incubators (LC) $\left(28^{\circ} \mathrm{C}, 80 \%\right.$ relative humidity, (12-hours photoperiod) until ecdysis was to adult stages. After identification, the ticks were stored in $70 \%$ methyl alcohol for processing.

\section{Pathogen detection}

Half of the specimens identified were assigned to the local Tick Museum (http://cloud.cnpgc.embrapa.br/controle-do-

carrapato-ms/museu-do-carrapato/) and the others were processed individually and subjected to DNA extraction by the guanidine isothio-cyanate-phenol technique, as describe by SANGIONI et al. (2005). Thereafter, they were tested with the Polymerase Chain Reaction (PCR) test to identify the presence of rickettsial infection. This test utilized the CS-78 (Forward) and CS-323 (reverse) primers, targeting a 401-bp fragment of the rickettsial citrate synthase gene (gltA) (LABRUNA et al., 2004).

\section{RESULTS AND DISCUSSION}

Two tick's species were found: Amblyomma sculptum and A. dubitatum. There were 1219 specimens collected, from which 1045 were $A$. sculptum (624 females/421 males), 174 were $A$. dubitatum (107 females/67 males) (Table 1), and 193 were nymphs. From these nymphs, 74 (37\%) were fed on rabbits prior to storage in a B.O.D. type incubator until they reached the adult phase. Of these nymphs, 37 individuals survived: 33 were $A$. sculptum and four were A. dubitatum.

Table 1. Ticks collected in a Cerrado fragment located within the urban area of Campo Grande, Mato Grosso do Sul, state, Brazil, by season, species, and gender, during the period from winter (July) 2012 to autumn (March) 2015.

\begin{tabular}{lccc}
\hline & \multicolumn{3}{c}{ Ticks } \\
\cline { 2 - 4 } Seasons & A. sculptum $(9 / \delta)$ & A. dubitatum $(9 / \delta)$ & Amblyomma spp. Nymphs \\
\hline Winter & $71(39 / 32)$ & $31(20 / 11)$ & 162 \\
Spring & $434(238 / 196)$ & $27(14 / 13)$ & 22 \\
Summer & $384(252 / 132)$ & $58(31 / 27)$ & 0 \\
Autumn & $156(95 / 61)$ & $58(42 / 16)$ & 9 \\
\hline Total & $1045(624 / 421)$ & $174(107 / 67)$ & 193 \\
\hline
\end{tabular}

The presence of larvae was observed during the winter of each year and the 2015 autumn. Regarding the investigation of the presence of Rickettsiae from the spotted fever group, 562 (50\%) adult ticks were subject to analysis using PCR. All of them tested negative for the presence of the agent. The same two species here collected with $\mathrm{CO}_{2}$ traps were collected by VERONEZ et al. (2010), in a Cerrado reserve in Uberlândia, Minas Gerais state (MG), during a two-year period. In addition, these two tick species are the most frequently species found in areas occupied by capybaras (SZABÓ et al., 2009; QUEIROGAS et al., 2012)

A. sculptum and $A$. dubitatum adults were observed during all seasons (Figure 1)

The A. sculptum population was higher than the A. dubitatum population in most seasons, except for the summer and autumn of the second year. Our results suggest that this was due to a decrease in the A. sculptum population, and not due to an increase in the A. dubitatum population.

Increased numbers of adults of A. sculptum have always occurred during seasons with the highest annual mean temperature, which correspond 
to spring and summer. In the first year, greater number of ticks was collected in summer, and in the followings years they occurred during the spring.
The higher adult occurrence of this species during spring and summer was also registered in Pedro Leopoldo, MG, Brazil (OLIVEIRA et al., 2000).

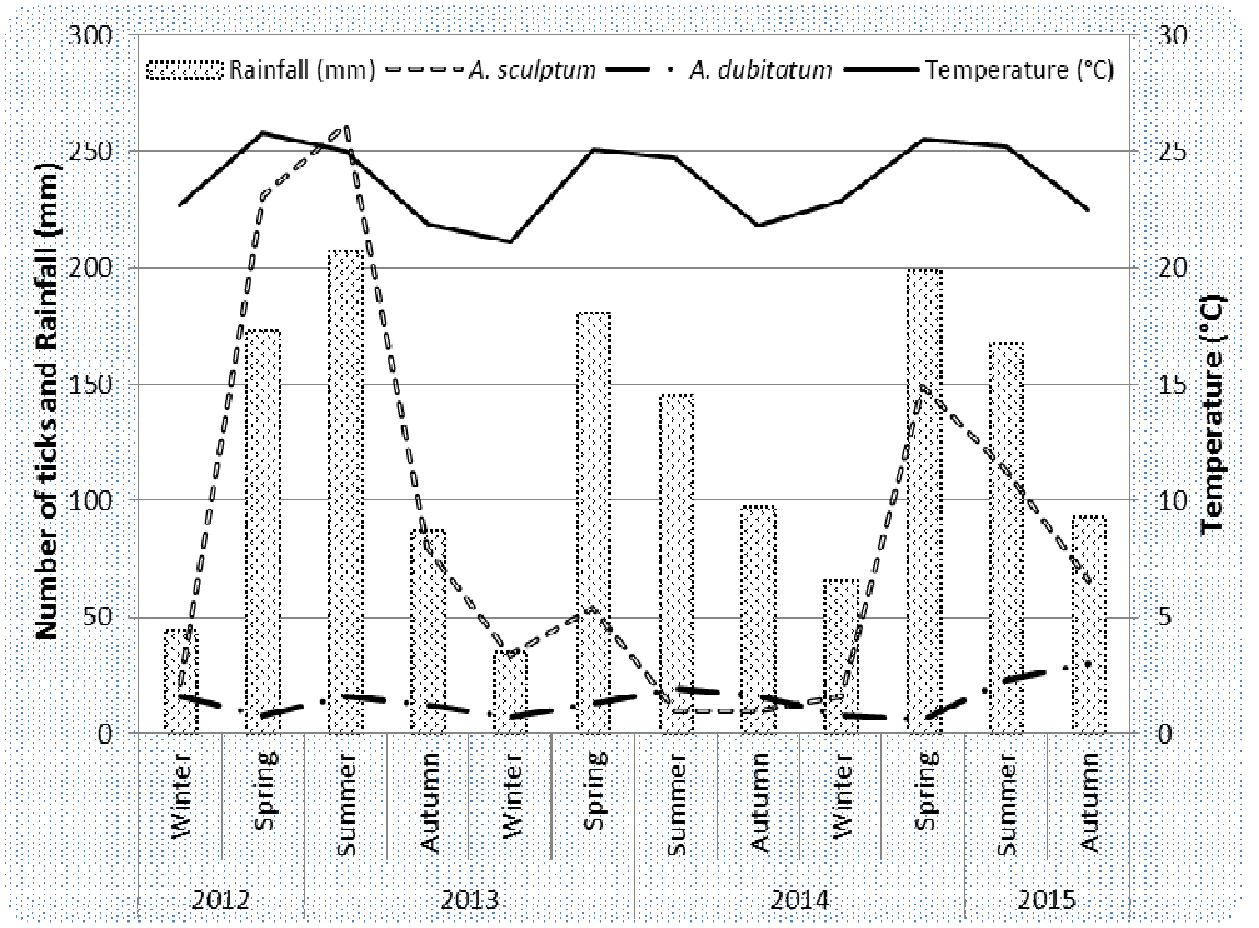

Figure 1. Tick population of Amblyomma dubitatum and Amblyomma sculptum, by season, during the period from the winter of 2012 until the autumn of 2015, accompanied by weather data [mean temperature ${ }^{\circ}$ C) and average of total monthly precipitation $(\mathrm{mm})$ ], in a cerrado fragment located within the urban area of Campo Grande, Mato Grosso do Sul, state, Brazil.

In this study, it was suggested that unfed free-living adults have low activity during winter, season characterized in the region by the occurrence of lower temperatures and photoperiod and decrease of relative air humidity. Consequently, we suggest that these factors may also play a role regarding the peaks of A. sculptum and A. dubitatum.

The A. sculptum population was 4.5 times higher in the first year than in the second year (Figure 1). It is suggested that this reduction is related to the change in the capybaras behavior due to the installation of a physical barrier in a part of the studied area. The barrier blocked their access to the courtyard's grass where they foraged, possibly causing them to migrate to another area of the campus. A significant decrease of tick population is seen when the host is removed (BRITES-NETO \& BRASIL, 2014). In the third year occurred the gradual return of the capybara in the area, suggesting that they became accustomed to the presence of the fence. In the first year, the highest number of $A$. dubitatum occurred in winter and summer, and in the following two years in summer and fall (Figure 1).The A. dubitatum population levels, in addition to being slightly higher than $14 \%$ of the total collected ticks, presented a small variation throughout the years and seasons.

There was no reduction of $A$. dubitatum population associated with the reduction of the capybara traffic during the second year. As observed by QUEIROGAS et al. (2012), our study also could not establish a correlation between the abundance of A. dubitatum and the capybara population. Due to the lack of other evidence that can support the stability of the A. dubitatum population, the presence of other hosts, such as small mammals and marsupials in the study area, probably contributed to their survival, as previously reported by DEBÁRBORA et al. (2014). Another possible contribution to the population stability of this species in comparison to the A. sculptum is that it thrives in wet and/or subject to flooded environments, as it is the case of the area of this study (SZABÓ et al., 2007; QUEIROGAS et al., 2012). 
All samples tested were negative for rickettsial infection. Since capybaras have been described as reservoir hosts for $R$. rickettsia, and $A$. sculptum a competent vector, our results cannot exclude the possible presence of $R$. rickettsii in the area of study (PACHECO et al., 2009; GUEDES et al., 2011). Only 50\% of the ticks were tested, therefore, if the infection rate in ticks is very low, as related by LABRUNA (2009), which mentions an infection rate varying from 0.04 to $1.3 \%$ for $R$. rickettsia, we might have not detected it in this study.

Both species found in this study deserve permanent surveillance, since A. sculptum is considered aggressive toward humans, especially in its immature forms (SZABÓ et al., 2013). The A. dubitatum role as a competent vector for human pathogens is still unknown, however it has been documented that this specie can bite humans and be infected with Spoted Fever Group Rickettsiae species (LABRUNA et al., 2004, LABRUNA et al., 2007; MATIAS et al., 2014).

\section{ACKNOWLEDGEMENTS}

National Council for Scientific and Technological Development (CNPq), Mato Grosso do Sul state Foundation of Teaching, Science and Technology (FUNDECT-MS).

RESUMO: Casos fatais de febre maculosa que foram relatados em alguns municípios brasileiros geralmente estão associados à presença de carrapatos e capivaras (Hydrochoerus hydrochaeris). Os fragmentos florestais urbanos onde este roedor está presente são de grande preocupação. Investigou-se aqui a diversidade de carrapatos livres e a ocorrência de carrapatos infectados por riquétsias em um desses fragmentos em Campo Grande, Mato Grosso do Sul. Desde o inverno de 2012 até o outono de 2015, usando armadilhas de $\mathrm{CO}_{2}$, foram coletados 1219 carrapatos, dos quais 1045 pertenciam à espécie Amblyomma sculptum e 174 pertenciam a A. dubitatum. Ambas as espécies foram mais abundantes na primavera (Setembro a Dezembro) e no verão (Dezembro a Março) . O DNA riquetsial não foi detectado em nenhum dos espécimes coletados; entretanto, uma das espécies encontradas, o A. sculptum é considerado o principal vetor da Febre Maculosa Brasileira, merecendo assim vigilância constante pelos Orgãos de Saúde Pública.

PALAVRAS-CHAVE: Amblyomma dubitatum. Amblyomma sculptum. Diversidade de Carrapatos. Rickettsia spp.

\section{REFERENCES}

ALMEIDA, R. F. C.; GARCIA, M. V.; CUNHA, R. C.; MATIAS, J.; SILVA, E. A.; MATOS, M. F. C.; ANDREOTTI, R. Ixodid fauna and zoonotic agents in ticks from dogs: first report of Rickettsia rickettsii in Rhipicephalus sanguineus in the state of Mato Grosso do Sul, mid-western Brazil. Exp. Appl. Acarol. v. 60, p. 63-72, 2013. https://doi.org/10.1007/s10493-012-9641-y

BARROS-BATTESTI, D. M.; ARZUA, M.; BECHARA, G.H. (Eds.). Carrapatos de importância médicoveterinária da Região Neotropical: Um guia ilustrado para identificação de espécies. Vox/International Consortium on Ticks and Tick-borne Diseases (ICTTD-3)/Butantan, São Paulo, 2006, 223p.

BRITES-NETO, J.; BRASIL, J. Epidemiological monitoring of ticks in public woods in a risk area for Brazilian Spotted Fever. BEPA,11, p. 7-15, 2014.

DEBÁRBORA, V. N.; MANGOLD, A. J.; OSCHEROV, E. B.; GUGLIELMONE, A. A.; NAVA, S. Study of the life cycle of Amblyomma dubitatum (Acari:Ixodidae) based on field and laboratory data. Exp. Appl. Acarol. v. 63, p. 93-105, 2014. https://doi.org/10.1007/s10493-014-9767-1

GUEDES, E.; LEITE, R. C.; PACHECO, R. C.; SILVEIRA, I.; LABRUNA, M. B. Rickettsia species infecting Amblyomma ticks from an area endemic for Brazilian spotted fever in Brazil. Rev. Bras. Parasitol. Vet. v. 20, p. 308-311, 2011. https://doi.org/10.1590/S1984-29612011000400009

LABRUNA, M. B.; WHITWORTH, T.; HORTA, M. C.; BOUYER, D. H.; MCBRIDE, J. W.; PINTER, A.; POPOV, V.; GENNARI, S. M.; WALKER, D. H. Rickettsia Species infecting Amblyomma cooperi ticks from 
an area in the State of São Paulo, Brazil, where Brazilian spotted fever is endemic. J. Clin. Microbiol. v. 42, p. 90-98, 2004. https://doi.org/10.1128/JCM.42.1.90-98.2004

LABRUNA, M. B.; PACHECO, R. C.; ATALIBA, A. C.; SZABÓ, M. P. J. Human parasitism by the capybara tick, Amblyomma dubitatum (Acari: Ixodidae) in Brazil. Entomol. News. v. 118, p. 77-80, 2007.

https://doi.org/10.3157/0013-872X(2007)118[77:HPBTCT]2.0.CO;2

LABRUNA, M. B. Ecology of Rickettsia in South America. Ann. N. Y. Acad. Sci. v. 1166, p. 156-166, 2009. https://doi.org/10.1111/j.1749-6632.2009.04516.x

LABRUNA, M. B.; NAVA, S.; MARCILI, A.; BARBIERI, A. R.; NUNES, P. H.; HORTA, M. C.; VENZAL, J. M. A new argasid tick species (Acari: Argasidae) associated with the rock cavy, Kerodon rupestris WiedNeuwied (Rodentia: Caviidae), in a semiarid region of Brazil. Parasit. Vectors. v. 9, p. 1-15, 2016. https://doi.org/10.1186/s13071-016-1796-7

MARTINS, T. F.; BARBIERI, A. R. M.; COSTA, F. B.; TERASSINI, F. A.; CAMARGO, L. M. A.; PETERKA, C. R. L.; PACHECO, R. C.; DIAS, R. A.; NUNES, P. H.; MARCILI, A.; SCOFIELD, A.; CAMPOS, A. K.; HORTA, M. C.; GUILLOUX, A. G. A.; BENATTI, H. R.; RAMIREZ, D. G.; BARROSBATTESTI D. M.; LABRUNA, M. B. Geographical distribution of Amblyomma cajennense (sensu lato) ticks (parasitiformes: ixodidae) in Brazil, with description of the nymph of A. cajennense (sensu stricto). Parasit Vectors. v. 9, p. 1-14, 2016. https://doi.org/10.1186/s13071-016-1460-2

MATIAS, J.; GARCIA, M. V.; CUNHA, R. C.; AGUIRRE, A. A. R.; BARROS, J. C.; CSORDAS, B. G.; ANDREOTTI, R. Spotted fever group Rickettsia in Amblyomma dubitatum tick from the urban area of Campo Grande, Mato Grosso do Sul, Brazil. Ticks Tick-borne Dis. v. 6, p. 107-110, 2014.

https://doi.org/10.1016/j.ttbdis.2014.10.001

OGRZEWALSKA, M.; MARTINS, T F.; CAPEK, M.; LITERAK, I.; LABRUNA, M. B. A Rickettsia parkerilike agent infecting Amblyomma calcaratum nymphs from wild birds in Mato Grosso do Sul, Brazil. Ticks Tick- borne Dis. v. 4, p. 145-147, 2013. https://doi.org/10.1016/j.ttbdis.2012.07.001

OLIVEIRA, P. R.; BORGES, L. M. F.; LOPES, C. M. L.; LEITE, R. C. Population dynamics of the free living stages of Amblyomma cajennense (Fabricius, 1787) (Acari: Ixodidae) on pastures of Pedro Leopoldo, Minas Gerais state, Brazil. Vet. Parasitol. v. 92, p. 295-301, 2000. https://doi.org/10.1016/S0304-4017(00)00322-8

PACHECO, R. C.; HORTA, M. C.; PINTER, A.; MORAES-FILHO, J.; MARTINS, T. F.; NARDI, M. S.; SOUZA, S. S. A. L.; SOUZA, C. E.; SZABÓ, M. P. J.; RICHTZENHAIN, I. J.; LABRUNA, M. B. Pesquisa de Rickettsia spp. em carrapatos Amblyomma cajennense e Amblyomma dubitatum no Estado de São Paulo.

Rev. Soc. Bras. Med. Trop. v. 42, p. 351-353, 2009. https://doi.org/10.1590/S0037-86822009000300023

QUEIROGAS, V. L.; DEL CLARO, K.; NASCIMENTO, A. R. T.; SZABO, M. P. J. Capybaras and ticks in the urban areas of Uberlândia, Minas Gerais, Brazil: ecological aspects for the epidemiology of tick-borne diseases. Exp. Appl. Acarol. v. 57, p. 75-82, 2012. https://doi.org/10.1007/s10493-012-9533-1

SANGIONI, L. A.; HORTA, M. C.; VIANNA, M. C.; GENNARI, S. M.; SOARES, R. M.; GALVÃO, M. A.; SCHUMAKER, T. T.; FERREIRA, F.; VIDOTTO, O.; LABRUNA, M. B. Rickettsial infection in animals and Brazilian spotted fever endemicity. Emerg. Infect. Dis. v. 11, p. 265-270, 2005.

https://doi.org/10.3201/eid1102.040656

SZABÓ, M. P. J.; CASTRO, M. B.; RAMOS, H. G. C.; GARCIA, M. V.; CASTAGNOLLI, K. C.; PINTER, A.; VERONEZ, V. A.; MAGALHÃES, G. M.; DUARTE, J. M. B.; LABRUNA, M. B. Species diversity and seasonality of free-living ticks (Acari: Ixodidae) in the natural habitat of wild Marsh deer (Blastocerus dichotomus) in Southeastern Brazil. Vet. Parasitol. v. 143, p. 147-154, 2007.

https://doi.org/10.1016/j.vetpar.2006.08.009 
SZABÓ, M. P. J.; LABRUNA, M. B.; GARCIA, M.V.; PINTER, A.; CASTAGNOLLI, K. C.; PACHECO, R. C.; CASTRO, M. B.; VERONEZ, V. A.; MAGALHÃES, G. M.; VOGLIOTTI, A.; DUARTE, J. M. B.

Ecologycal aspects of free-living ticks (Acari: Ixodidae) on animal trails in a Atlantic rainforest of Southeastern Brazil. Ann. Trop. Med. Parasitol. v. 103, p. 57-72, 2009. https://doi.org/10.1179/136485909X384956

SZABÓ, M. P. J.; PINTER, A.; LABRUNA, M. B. Ecology, biology and distribution of spotted-fever tick vectors in Brazil. Front. Cell. Infect. Microbiol. v. 3, p. 1-9, 2013. https://doi.org/10.3389/fcimb.2013.00027

VERONEZ, V. A.; FREITAS, B. Z.; OLEGÁRIO, M. M. M.; CARVALHO, W. M.; PASCOLI, G. V. T.;

THORGA, K.; GARCIA, M. V.; SZABÓ, M. P. J. Ticks (Acari: Ixodidae) within various phytophysiognomies of a Cerrado reserve in Uberlândia, Minas Gerais, Brazil. Exp. Appl. Acarol. v. 50, p. 169-179, 2010. https://doi.org/10.1007/s10493-009-9294-7

WOLF, R. W.; ARAGONA, M.; MUÑOZ-LEAL, S.; PINTO, L. B.; MELO, A. L.T.; BRAGA, I. A.; COSTA, J. S.; MARTINS, T. F.; MARCILI, A.; PACHECO, R. C.; LABRUNA, M. B.; AGUIAR, D. M. Novel Babesia and Hepatozoon agents infecting non-volant small mammals in the Brazilian Pantanal, with the first record of the tick Ornithodoros guaporensis in Brazil. Ticks Tick Borne Dis. v. 7, p. 449-456, 2016.

https://doi.org/10.1016/j.ttbdis.2016.01.005 